\title{
Autonomy and international organisations
}

\author{
Andrew P. Cortell ${ }^{1}$. Susan Peterson ${ }^{2}$
}

Published online: 5 October 2021

(c) Springer Nature Limited 2021

\begin{abstract}
For two decades scholars have used insights from constructivist approaches and principal-agent (P-A) theory to understand the relationship between states and international organisations (IOs). Together, these works identify the conditions under which IOs can operate independently of states, although they have yet to explain when and why IO bureaucrats are likely to do so. Nor do they articulate a clear and consistent definition of autonomy. In this article, we seek to fill these gaps. We advance a narrow understanding of autonomy that distinguishes unintended behaviour from the intended independence of IO bureaucrats, before developing a threestage, integrative explanation for the conditions under which IO bureaucrats act autonomously. First, we borrow from constructivist approaches a focus on staffing rules and the identity of IO bureaucrats to explain the sources of these agents' preferences. Second, we add insights from work on exogenous pressures for changecrises and critical junctures - to explain when and why IO bureaucrats will advance their preferences. Third, we incorporate P-A theory's attention to an IO's institutional design, along with insights from literature on domestic institutions, to explain when bureaucrats can implement their preferences. Case studies of the World Health Organization (WHO) and the World Trade Organization (WTO) illustrate our argument.
\end{abstract}

Keywords Bureaucratic autonomy · Delegation · International organisations · Principal-agent relations · World Health Organization $(\mathrm{WHO}) \cdot$ World Trade Organization (WTO)

Andrew P. Cortell acortell@aum.edu

1 Department of Political Science and Public Administration, Auburn University at Montgomery, Montgomery, AL, USA

2 Department of Government, William \& Mary, Williamsburg, VA, USA 


\section{Introduction}

Over the past two decades international relations scholars' use of insights from two major theoretical traditions, constructivism and principal-agent (P-A) theory, have enriched our understanding of international organisations' (IOs) capacity for independent action. Constructivist approaches shed light on how factors such as staffing procedures lead IO bureaucrats to develop their own preferences (e.g. Barnett and Finnemore 2004; Chwieroth 2008a, 2008b). P-A approaches, in contrast, highlight how the decision-making rules governing oversight among the member state principals and the grant of authority from the states to the IO agent, known as the delegation contract, can affect international bureaucrats' ability to act autonomously (e.g. Hawkins et al. 2006a). Together, these influential literatures identify the conditions under which IOs can operate independently of states, although this existing work continues to be characterised by two shortcomings.

First, scholars working in both traditions often use the term 'autonomy' to mean different things and in the process overestimate the extent of IO autonomy. This existing work, for example, blurs the distinction between autonomous actioninternational bureaucrats' behaviour that is outside the parameters of their authority - and discretion - the independence that member states grant to bureaucrats to fulfill their delegated mandate. These two forms of independence capture distinct behaviours and presuppose different institutional conditions. Drawing on Hawkins et al. (2006b), we define autonomy as outcomes that member states did not intend, and we establish the presence or absence of autonomy by reference to the terms of the delegation contract. This approach narrows the range of cases of autonomous IO behaviour but clearly identifies instances in which the agents acted in ways the principals did not intend. Such distinctions are a necessary step in developing a clear baseline to systematically compare behaviour across IOs, a key goal of recent efforts to explain IO independence (Brown 2010; Haftel and Thompson 2006; Hooghe and Marks 2015; Hooghe et al. 2017).

Second, while the existing literature offers important insights about preference formation, the delegation contract, and coordination rules, it does not identify the conditions under which IO bureaucrats act on their preferences. As Knill et al. (2019: 84) observe, 'the implicit assumption in many studies [...] is that formal discretion is automatically exploited by [IOs] in order to pursue [their] own objectives deviating from those of their political masters'. ${ }^{1}$ We remedy this limitation by developing a three-stage, integrative explanation of the conditions under which IO bureaucrats are likely to act autonomously. The first stage draws on constructivist approaches that focus on staffing rules and identity to explain the sources of IO bureaucrats' preferences. The second stage of our explanation fills the key gap in the existing literature. We build on work on exogenous pressures for change-crises

\footnotetext{
1 Knill et al. (2019: 85) address the problem by focusing on the question of why some IO bureaucracies are 'more actively trying to influence the policy process than others'. Their explanation focuses on 'administrative styles [defined as ...] relatively stable behavioral orientations characterizing an organizational body'.
} 
and critical junctures - to explain when and why bureaucrats advance their preferences and seek to act autonomously. Such external pressures can have implications for the IO's organisational security, leading bureaucrats to take actions to stabilise or enhance the IO's position. The third stage incorporates P-A theory's attention to institutional design, as well as insights from literature on domestic institutions, to explain when IO bureaucrats are able to implement their preferences. Our threestage explanation expects that the likelihood that IO bureaucrats will act autonomously increases when the following factors are present: staff are selected on the basis of their specialised knowledge; an external pressure influences the IO's ability to fulfill its mandate; the delegation contract grants discretion to bureaucrats; voting rules require coordination among multiple member states to restrain IO bureaucrats; and the structure of decision-making within the IO's bureaucratic apparatus limits the number of units involved in the policy area.

Case studies of the World Health Organization (WHO) and the World Trade Organization (WTO) illustrate our argument. We selected these two IOs for several reasons. First, both IOs have exhibited autonomous behaviour-the WHO in 1970 in response to a cholera outbreak in Guinea and in 2003 in response to the SARS crisis and the WTO's Appellate Body (AB) in procedural rulings in 1998 and 2000 involving non-governmental organisations (NGOs). Second, since such behaviour is exceptional in these IOs' histories, and their organisational design has remained largely unchanged, a longitudinal analysis helps identify the factors that led bureaucrats in each organisation to act outside their mandates. Finally, comparing these two important organisations helps remedy a limitation of many existing studies, which usually explore only a single case of IO autonomy.

This article has two primary goals: to explain the benefits of defining autonomy as agent behaviour that falls outside the delegation contract; and to offer an explanation for the conditions under which IO bureaucrats are likely to act autonomously. The rest of the article proceeds in five steps. First, we clarify the outcome we seek to explain, IO autonomy. Next, we discuss constructivist and P-A approaches, highlighting the key contributions we build on and the gaps we seek to fill. The third section develops our three-stage explanation for IO autonomy; and the fourth section presents the two longitudinal case studies. The final section identifies our core claims and main findings.

\section{Understanding the autonomy of international organisations}

Understanding IO behaviour starts with the formal delegation contract. In this contract, the original agreement establishing the IO or a formal re-contract, member states delimit expectations for IO bureaucrats' behaviour. By bureaucrats, we mean the individuals who occupy positions within the IO's secretariat or administrative apparatus. These individuals are referred to variously as international or IO bureaucrats, international civil servants, or staff members. We recognise that an IO is not a unitary actor and take up that point in the argument section. Here, we discuss our outcome of interest, IO autonomy. 
Autonomy is behaviour that is not identified in the delegation contract. As Hawkins et al. (2006b: 8) note, 'autonomy is the range of potential independent action available to the agent [...] after the principal has selected screening, monitoring, and sanctioning mechanisms intended to constrain their behavior'. This unintended behaviour includes independent action that 'can be used to benefit or undermine the principal' (Hawkins et al. 2006b: 8). In other words, autonomy emerges only when IO bureaucrats 'exceed the margin of maneuver that is formally given to them' (Knill et al. 2019: 86). ${ }^{2}$ Unlike autonomy, independent behaviour that is included in the delegation contract is discretion; principals intentionally grant their agent leeway to fulfill delegated tasks (Hawkins et al. 2006b: 8). The delegation contract, in short, establishes the IO bureaucrats' range of discretion. Distinguishing between autonomy and discretion and adopting a relatively narrow definition of autonomy as behaviour outside the delegation contract highlights the dichotomous nature of our dependent variable: either an IO acts as its member states intended, or it acts in unintended ways and exhibits autonomy.

This understanding of autonomy overcomes several potential pitfalls. First, some students of IOs (e.g. Barnett and Finnemore 2004; Chwieroth 2008a; Graham 2014; Nielson and Tierney 2003) equate autonomy with bureaucrats' divergence from state expectations. This approach, however, fails to explain how state expectations are identified. Using the delegation contract overcomes this problem by providing a common baseline for analysis. We recognise that some contracts may be imprecisely written, so additional steps may be needed to measure member states' intentions. For example, a delegation contract may lead to different interpretations of states' intentions. We clarify those intentions by examining member states' statements during the formulation of the (original or more recent) agreement and other aspects of the agreement that provide a context for the specific responsibilities in question. Additionally, if a specific responsibility is absent from the delegation contract, we must assume states intended to exclude it, whether by design or because of lack of agreement. Other contracts may include contradictory elements that emerge when states layer new agreements on top of the existing agreements. In such situations, the most recent agreement can signal member states' expectations, especially for IOs with long histories. States' declarations during subsequent negotiations also identify their intentions when there are overlapping contracts.

Second, limiting autonomy to unintended behaviour means that not all IO bureaucrats who influence state preferences and international outcomes are autonomous. States create IOs to help solve problems, and states delegate discretion to IOs to carry out their assigned tasks. As a consequence, we should expect international bureaucrats' influence and independence; in fact, it is intended by the design of some IOs (Johnson 2014), and bureaucrats frequently play a significant role in shaping debates, negotiations, and state behaviour through their agenda-setting functions (see Barnett and Finnemore 2004). Many students of IOs (e.g. Barnett and Finnemore 2004: 28; Biermann and Siebenhuner 2009: 345; Brown 2010) conflate

\footnotetext{
${ }^{2}$ Knill et al. (2019: 86) refer more generally to 'bureaucratic agency', which includes both discretion and autonomy.
} 
discretion and autonomy, ${ }^{3}$ while others fail to explain what they mean by autonomy (e.g. Bauer and Ege 2016; Hooghe et al. 2017). Nevertheless, autonomy goes beyond independence, influence or authority to include unintended behaviour, making the discretion-autonomy distinction important for understanding the role IOs play in world politics.

Third, understanding autonomy as behaviour outside the delegation contract distinguishes it from IO behaviour that conflicts with state interests. Because P-A approaches take a conflict between principals' and agents' interests as their starting point, many P-A scholars conceptualise autonomy in purely negative termsas actions that do not advance the principals' interests (see Nielson and Tierney 2003: 246). Other scholars note obstacles to specifying a priori whether or not an agent's unintended actions are considered undesired by the principal(s). As Barnett and Finnemore (2004: 35-36) observe, ' $[\mathrm{t}]$ he problem here is that most IOs have multiple audiences, multiple principals, and multiple missions. Consequently, it is difficult analytically to label a behavior "bad" or even "undesirable", since most behaviors serve someone's interest'. Equating IO autonomy with actions that are not identified in the delegation contract divorces autonomy from a judgment of its consequences and enhances the prospect that multiple observers will agree independently on whether or not an action is autonomous.

Finally, as some IO students (e.g. Barnett and Coleman 2005: 601; Barnett and Finnemore 2004; Hawkins et al. 2006b: 8) note, autonomous action can include nonactions, such as the agent's independent decisions not to act in the face of member states' preexisting expectations of action. The most reliable way to determine whether an IO's inaction represents autonomy requires an understanding of member states' expectations as specified in the delegation contract.

In sum, we employ a straightforward, but not yet widely employed, understanding of IO autonomy as the actions or non-actions of international bureaucrats that member states did not intend as measured by the terms of the original or revised delegation contract. This definition distinguishes autonomy from other types of behaviour, including cases in which an IO may agenda-set, influence state preferences, and affect international outcomes. Only a subset of these behaviours - those actions that were unintended by the member states under the terms of the delegation contract-comprise autonomous behaviour. Without such an understanding, it is easy to overestimate the extent of IO autonomy. ${ }^{4}$

\footnotetext{
3 Barnett and Finnemore's (2004) use of 'autonomy by design' highlights the problem. The agent is not autonomous in the sense of acting in ways unexpected by the member states; instead, it has been delegated discretion to accomplish its mission.

4 Bauer and Ege (2016) suggest the potential for this problem. They use ten structural characteristics to code fifteen IOs for their capacity for 'autonomy of will' and 'autonomy of action'. However, they do not provide a coding scheme to determine whether or not the IO bureaucrats' actions accord with member states' intentions.
} 


\section{Existing explanations of 10 autonomy}

Insights from two major intellectual approaches - constructivism and P-A theoryhave guided the field's understanding of the sources of IO autonomy for the past two decades. In this section, we explain the core contributions of each approach, emphasising areas that provide the foundation for our own explanation.

Scholars working from a constructivist perspective focus on the sources of international bureaucrats' preferences, particularly the role of identity and IOs' staffing rules. 'Personnel configurations and recruitment procedures matter because the type of individuals and the credentials demanded can exert a significant impact on an organization's views' (Chwieroth 2008a: 493). Professional training is an important source of identity that shapes bureaucrats' understandings of their mandate and the ways to achieve it. ${ }^{5}$ As Chwieroth (2008b: 134) notes, 'Professions are critical agents of social construction, possessing a constitutive power that enables them to offer understandings of and to fix meanings to particular social objects and to define the legitimate and the possible'. When international bureaucrats are professionals trained in a particular field of expertise, their 'strategies or choice sets [will be] constrained as they internalize particular logics of appropriateness and come to accept particular causal beliefs about the world that are strongly influenced by their bureaucratic environment' (Nielson, Tierney and Weaver 2006: 110). Their professional training, in short, influences IO officials' solutions to problems and their embrace of new policies (Barnett and Finnemore 2004: 24; Cortell and Peterson 2006: 260-61).

Constructivist works offer crucial insights into the sources and consequences of bureaucrats' preferences, but they tend not to 'explore the factors that enable international organisations to advance their interests' (Chorev 2012: 20). Such accounts explain the absence of agent-initiated strategies only when bureaucrats do not want them. By focusing so heavily on preferences, then, constructivists tend to ignore the institutional context in which bureaucrats operate. ${ }^{6}$ Since these arguments generally assume that IO bureaucrats act on their independent preferences, they tell us little about whether or when bureaucrats actually do act.

P-A scholars, by contrast, emphasise two aspects of the IO's institutional design that impact bureaucrats' ability to act independently, although in the process they generally assume what constructivists problematise, that agents have independent preferences. First, P-A theory draws our attention to variations in the degree of discretion granted to the staff to fulfill the IO's mandate. Under rule-based delegation, member states establish specific guidelines for how delegated tasks should be fulfilled; with discretion-based delegation, in contrast, states establish only the goals they want achieved, giving the agent leeway to fulfill them (Hawkins et al. 2006b: 27). Regardless of which form of delegation occurs, P-A approaches expect 'principals [to] attempt to structure the incentives of agents ex ante so that it is in the interests of those agents to carry out their principals' desires faithfully ex post' (Hawkins

\footnotetext{
5 The staff's professional expertise is a relatively unproblematic social trait to measure.

${ }^{6}$ Even when existing work considers such factors, they remain underdeveloped (e.g. Chwieroth 2008a: 494).
} 
et al. 2006b: 26). Principals design mechanisms of control, such as screening and selection procedures, to identify agents who share their preferences. Second, member state voting rules influence whether IO bureaucrats can implement their preferences. Most IOs are 'collective principals' comprised of multiple states (Nielson and Tierney 2003: 247). Accordingly, P-A theorists focus on the rules that coordinate the collective principal's oversight of the IO. A dispersed or decentralised voting structure that empowers many member states makes it difficult for principals to reconcile preference heterogeneity and provides an opening for the agent to implement its own preferences. Voting structures that concentrate oversight in few states, in contrast, reduce the diversity of state interests, thereby increasing the credibility of principals' threats and restraining an agent's willingness to pursue unintended actions (Cortell and Peterson 2006: 262; Hawkins et al. 2006a). ${ }^{7}$

For P-A scholars, these two aspects of the IO's institutional design together influence an agent's potential for autonomy. IO autonomy is most likely when discretionbased delegation is coupled with dispersed voting rules, as the international bureaucrats will have less confidence in member states' ability to re-contract or impose sanctions in response to unanticipated and unwanted behaviour. Although P-A theory makes an important contribution to our understanding of IO autonomy by highlighting how an organisation's institutional design affects bureaucrats' capacity for autonomy, this theoretical approach offers little insight into bureaucrats' preferences or the conditions under which staff seek to operate outside the delegation contract. As Gould (2006: 283) notes, 'While the P-A approach may help scholars determine how much "autonomy" (or potential slack) an IO may be able to take advantage of, it cannot necessarily indicate whether the agent will actually take advantage of that autonomy'. 8

The two leading perspectives shed light on how staffing rules, delegation contracts, and voting rules affect the potential for IO autonomy, but existing works leave underdeveloped the conditions under which agents act on their preferences. In the next section we develop a theory of IO autonomy that accounts for this behaviour, integrating the key explanatory variables from constructivist and P-A approaches with insights from work on critical junctures, windows of opportunity, resource dependence, and domestic institutions.

\section{Towards an explanation of 10 autonomy}

Table 1 summarises the three stages of our integrative explanation for IO autonomy. As we noted in the previous section, existing work focuses on either the first or last stage of this argument-why staff develop independent preferences and when they can implement those preferences. We add the missing intermediate step explaining

\footnotetext{
7 Copelovitch (2010: 57-58) argues that this claim holds only when powerful member states have intense preferences about an issue.

8 This is true even in applications of P-A theory that explore the relationship between the agent and third parties (Hawkins and Jacoby 2008) or those that problematise the structure of the agent (Graham 2014).
} 


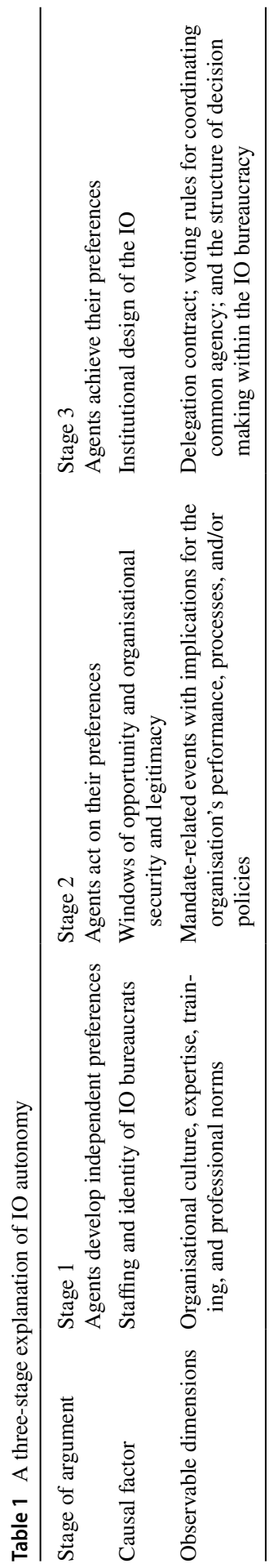

我这 
when and why IO bureaucrats decide to act on their preferences. To do so, we focus on windows of opportunity and their impact on organisational security. Together, the three stages identify five independent variables: staffing rules; windows of opportunity; and the institutional design of the IO, which includes the type of delegation contract, members' voting rules, and the decision-making structure. In this section we explain the causal factors and processes involved in each stage, discuss the relationship among the three stages, and identify the conditions that enable IO bureaucrats to act autonomously.

Logically, explaining IO autonomy must start with the sources of international bureaucrats' preferences. Accordingly, the first stage of our explanation focuses on the IO's staffing rules, specifically whether or not the staff share a common profession and training. As the constructivist approaches discussed above show, professional training creates a shared culture and identity among an IO's staff. The shared identity of, say, international lawyers or public health officials leads them to form common assumptions about how to interpret information and challenges. Their professional role, in short, becomes the lens through which they understand their mandate and the best ways to achieve it.

The second stage of our argument examines a largely unexplored question: when and why do agents act on their preferences? Historical institutionalist work on crises and critical junctures provides a starting point for understanding attempts by staff to take autonomous actions unintended by the IO's member states. Critical junctures represent 'relatively short periods of time during which there is a substantially heightened probability that agents' choices will affect the outcome of interest' (Capoccia and Kelemen 2007: 248). To understand the importance of critical junctures to IO autonomy, we draw on a related literature emphasising a link between 'windows of opportunity', and domestic institutional and policy changes. Windows open in response to exogenous pressures like crises, shocks, or more focused challenges that appear to discredit existing institutions, raise concerns about current policies, or affirm existing views and, therefore, highlight the potential benefits of action (e.g. Cortell and Peterson 1999; Keeler 1993; Kingdon 1984). ${ }^{9}$ Reformminded domestic actors capitalise on the new environment when doing so advances their preferences.

A similar approach helps explain when IO agents act autonomously. Existing work explores how principals and agents adapt to changing circumstances. For example, some P-A theorists examine the impact of external challenges on principals' ability to control IO bureaucrats (Nielson and Tierney 2003) and why principals might be willing to delegate discretion to new IOs (Johnson and Urpelainen 2014). The focus of that work, however, is on principals' capabilities and incentives. Our approach is closer to that offered by some constructivists, who see the external environment as a source of stimuli for IO bureaucrats (Barnett and Finnemore 2004). Existing work, however, focuses on the impact of only a narrow range of external challenges: 'rapid global change' (Barnett and Finnemore 2004: 162) or

\footnotetext{
9 Kingdon (1984) introduced the term 'window of opportunity' to identify openings for advocates of change.
} 
international pressures to conform (Barnett and Coleman 2005). Our explanation provides a fuller understanding of the interaction between IOs and their external environments.

Multiple factors can open a window of opportunity for IO staff, and different triggers can be relevant across time and issue area. As Capoccia and Kelemen (2007: 349) note, 'the occurrence of a critical juncture for one institution need not constitute a critical juncture with respect to all of its counterparts'. Developments within and related to an IO's area can create openings for the staff to act. The key determinant for a window to open is whether an exogenous pressure affects the status quo in an IO's activities or area of authority. The relevant triggering events include those that have implications for the organisation's performance, processes, and/or policies.

Exogenous pressures are not limited to threats to the IO's position or status. ${ }^{10}$ External events 'are interpreted in terms of [actors'] existing ideational frames' (Natorski 2016: 647). As a consequence, IO bureaucrats may view such events positively_as confirming the utility and/or legitimacy of prevailing ideas (see Legro 2000) - thereby empowering staff to act on those ideas.

External developments trigger international bureaucrats to act on their preferences. The more environmental pressures positively or negatively impact an organisation's ability to fulfill its mandate, the more likely the staff are to act. These pressures can influence the IO's strategic concerns or organisational security (Barnett and Coleman 2005). Chorev (2012: 24-25, 26-27) describes these strategic concerns in terms of 'resource dependence', the organisation's reliance on member states' financial support, and 'normative dependence', the IO's need for symbolic resources and legitimacy. ${ }^{11}$ As a consequence, 'IOs are likely to be very attentive to their legitimacy and whether they are perceived as serving ends valued by international society in general and key constituencies in particular' (Barnett and Coleman 2005: 598).

Bureaucrats' sense of their organisational security creates material or symbolic incentives for action. In the case of organisational insecurity, bureaucrats worry that the IO's 'relevance is questioned', there are 'broader cultural shifts that potentially leave it out of synch with its normative environment, and, most critically, these and other factors challenge the organization's resource base' (Barnett and Coleman 2005: 599). ${ }^{12}$ If the IO's organisational security is threatened, staff will seek to consolidate their standing and resources, advancing changes to the existing institutions and/or policies that seek to stabilise member states' and other constituents' political and/or financial support (see Knill et al. 2019: 91). Similarly, bureaucrats are likely to act when environmental pressures increase organisational security. When events demonstrate the need for the IO's services or expertise, affirm the logic and/or value

\footnotetext{
${ }^{10}$ For a recent approach that conceptualises the external environment only in terms of challenges, see Knill et al. (2019: 88-91).

11 Resource dependence theory (RDT), on which Chorev (2012) draws, focuses on the reliance of organisations on external support for their operation and survival, especially on inter-organisational resource dependence. For a discussion of RDT's applicability to IOs, see Biermann and Harsch (2017).

12 The authors argue that organisational insecurity increases in the presence of any of these factors.
} 
of its initiatives, or provide it with new sources of funding or support, they confirm the legitimacy of the organisation and its policies. Such developments increase the probability that bureaucrats will seek to expand the IO's activities by engaging in new initiatives within existing policy areas, moving into new policy areas, or modifying existing processes to facilitate future actions.

When a window of opportunity opens, international bureaucrats face incentives to capitalise on it, whether to stabilise or advance the IO's institutional position. In both cases, existing preferences and interests will guide staff members' responses to an exogenous pressure. One significant source of those preferences, as we note above, is the organisation's culture, specifically its bureaucrats' professional training. In the face of exogenous developments that challenge or reinforce their organisational security, international bureaucrats draw on their existing culture and beliefs to devise ways to protect and/or extend their organisation's authority, resources, and legitimacy (see Barnett and Finnemore 2004: 162).

The third and final stage of our explanation focuses on when IO bureaucrats who act on their preferences succeed in implementing them. The IO's institutional design impacts whether or not staff can engage in autonomous action. That outcome is a function of institutions establishing both the relationship between the member states and the IO agent and the structure of the IO bureaucracy itself. P-A approaches lead us to expect that bureaucrats are likely to succeed only when two conditions appear concurrently: bureaucrats have been granted discretion on how to fullfil their delegated mandate; ${ }^{13}$ and the IO has dispersed voting rules requiring the agreement of many states to approve an action.

Research on domestic institutions suggests an additional constraint on agents' ability to achieve their goals, the structure of decision-making authority within the IO. These studies (e.g. Ikenberry et al. 1988), which explore how institutions affect actors' roles and capacities in the national arena, are relevant to an understanding of when the IO can act more or less like a unitary actor. In particular, when multiple subunits of the IO's bureaucracy play a role in a policy area, it will be difficult for any single subunit to achieve its preferences if they disagree. When fewer units are involved, bureaucrats who act on their preferences will have greater capacity to implement them. Overlapping authority requires an independent-minded unit or a strong organisational leader to persuade others of the merits of acting outside the delegation contract. As Hall and Woods (2018: 873) note, the ability and willingness of IO staff members and executive heads to overcome constraints vary, depending on their personality, leadership style, skills, and risk propensity, and it is difficult to generalise about such factors. Thus, IO autonomy is less likely when decisionmaking authority within its bureaucratic agent is dispersed.

In sum, our three-stage explanation indicates that the likelihood that IO agents will engage in autonomous behaviour increases when several factors are present: IO bureaucrats are selected on the basis of their specialised training or expertise;

\footnotetext{
13 Although discretion may enable an agent to act autonomously, the two behavioural outcomes are distinct. As P-A approaches maintain, agent discretion with respect to how the mandate is met is an intended outcome, whereas autonomy represents agent actions that the principal did not intend.
} 
environmental pressures lead IO bureaucrats to believe that their organisational security has been positively or negatively impacted; the delegation contract grants bureaucrats discretion; voting rules require the approval of multiple member states; and the structure of decision-making within the IO's bureaucratic apparatus limits the number of units involved in the policy area. Each factor can vary over time with respect to a single IO or across different IOs. In practice, however, changes in staffing and voting rules become less likely over time. Such changes would require member states to agree to a different type of $\mathrm{IO}$, an unlikely prospect given preexisting voting rules and differences in states' interests and power.

\section{Explaining autonomy in the WHO and WTO}

This section illustrates our argument with applications to the WHO and WTO, which we selected for two reasons. First, each IO exhibits variation over time in our dependent variable; throughout most of their histories both IOs have adhered to their delegation contracts and only infrequently acted autonomously. We employ longitudinal case studies that allow us to include observations of both autonomy and discretion. This method follows Ege et al.'s (2020: 559) observation that '[t]o advance the state of the art [on IO bureaucracies] more comparative research designs that pay attention to including variation in [...] bureaucratic influence [...] are needed' ${ }^{14}$ Second, both IOs share a number of important characteristics: a bureaucracy staffed by experts in their issue area, discretion-based delegation, and dispersed voting rules. These similarities enable us to explore the within-case variations that lead agents to act on their preferences.

We begin each case by establishing that each IO's bureaucracy has the potential to exercise autonomy. ${ }^{15}$ To do so, we examine the factors that enable IO staffs to form independent preferences and act on them. Next, we survey the history of each IO to show that both organisations advanced autonomous actions only in the face of an external event that threatened their organisational security. Finally, we explain how member states responded to these actions and the consequences for future autonomy.

\section{The World Health Organization}

Established in 1948 as the 'directing and coordinating authority on international health work' (WHO 1948: Preamble), the WHO today includes 194 member states. Together, the representatives of these states form the World Health Assembly (WHA), the WHO's highest policymaking body. The WHA elects the Executive Board (EB) to advise, facilitate the work of, and implement the WHA's decisions. The EB comprises 34 medical doctors, public health experts, scientists, epidemiologists, health economists, and other technical experts who serve as individuals, not

\footnotetext{
14 The original refers to research on 'international public administration'. The authors use that term to refer to international organisations' secretariats and international bureaucrats.

15 Some of the discussion of both cases draws on Cortell and Peterson (2006).
}

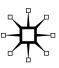


national representatives. This body nominates and the WHA appoints the WHO's director-general, who oversees staff of more than 7,000 medical, public health, epidemiological, and other technical specialists. The WHO staff are dispersed among the headquarters in Geneva and six regional offices, which enjoy significant autonomy over their budgets, staff, and policies.

The founding states imbued the WHO's bureaucrats with more discretion in some areas than others. Although the director-general drafts the budget, the WHA, not the staff, possesses the authority to apportion expenses to member states, distribute resources, and set policy by passing resolutions, regulations, and conventions. The WHO's bureaucracy enjoys greater discretion to fulfill its delegated responsibility to 'provide information, counsel and assistance in the field of health' (WHO 1948: II, 2, q). Staff gather and disseminate information, issue recommendations, and publish expert reports. The director-general enjoys considerable authority in this area, including the power to appoint both expert advisory panels to report on developments within their fields and expert committees and scientific groups to study particular international health issues (Jacobson 1973: 201-202). Individual states or coalitions of states cannot overturn the findings of these reports, which require only the director-general's approval to be published and guide WHO personnel and medical professionals around the world (Jacobson 1973: 202).

The staff's discretion has been more narrowly defined in the realm of disease surveillance and response. Originally adopted in 1951 as the International Sanitary Regulations (ISR) and revised and renamed the International Health Regulations (IHR) in 1969, the IHR are designed to 'ensure the maximum security against the international spread of diseases with a minimum interference with world traffic' (WHO 1983: Foreword). The regulations required states to notify the WHO of even a single case of cholera, plague, or yellow fever. ${ }^{16}$ This requirement was intended to form 'the backbone of WHO's international surveillance activities on the diseases subject to the IHR' (Fidler 2004: 33). It meant, however, that the WHO had to rely on member states to report outbreaks, but states had no obligation to report outbreaks of anything other than these three diseases.

Altering the IHR requires support within the WHA, where voting rules disperse authority. 'The [World] Health Assembly aims to work on consensus and nearly all resolutions are adopted without a vote' (WHO 2008). When the WHA votes, however, questions are decided by majority rule, although 'important questions'-regulations, resolutions, budget approval, and amendments to the constitution-require a two-thirds majority (WHO 2008, WHO 1948: Art. 60). In short, several of the conditions conducive to IO autonomy exist within the structure of the WHO: IO agents are selected on the basis of their expertise, those staff enjoy discretion-based delegation, and decision-making authority among member states is dispersed.

WHO bureaucrats have long exhibited independent preferences. The directorgeneral and EB members serve as individual health experts, rather than national representatives, and they share with the health professionals in the secretariat and expert committees a worldview that is infused by the IO's mission to pursue 'the

16 This list also included smallpox before its eradication. 
attainment by all peoples of the highest possible level of health' (WHO 1948: Preamble). As Chorev (2012) shows, historically WHO staff have advanced their own health agenda. They actively lobbied states to redefine the New International Economic Order of the 1970s and 1980s to include a focus on primary health care and social development. In the 1990s and 2000s WHO officials highlighted the importance of health for economic growth, turning the states' neoliberal agenda 'on its head' (Chorev 2012: 171). WHO bureaucrats also mobilised state support for a treaty on tobacco control and advocated a controversial position on an agreement to allow improved access to AIDS drugs, despite opposition from tobacco and pharmaceutical interests in major donor states (Chorev 2012: 10). In all of these areas, the WHO staff acted on their shared professional understanding and discretion to provide information and advice to shape state preferences and fulfill the IO's overall mandate.

At the same time, strategic concerns also drive WHO bureaucrats' preferences. The staff's capacity to achieve its goals is limited by its dependence on member states' continued financial support. Regular budget funds are assessed according to the states' ability to pay, but these contributions were frozen in the 1980s and have since declined. These assessed contributions comprise less than 20 percent of the WHO's financing, leaving voluntary state contributions and funds from other organisations to cover the remaining expenses (WHO 'How WHO is Funded'). This knowledge induces caution in pursuit of principled ideas when they conflict with member states' preferences. WHO bureaucrats have been particularly sensitive about efforts to expand the scope of the agency's mandate. As then Director-General Halfdan Mahler warned in 1983, the WHO should not be 'lured astray into fields beyond our constitutional competence, [...] those very minefields that we have been trying to avoid in the interest first and foremost of the health of the deprived peoples living in the Third World. None of us would want to blow up our Organization' (Williams 1987: 63).

Whether and when WHO bureaucrats attempted to advance their preferences depended on external pressures. In the area of disease surveillance and response, WHO staff largely adhered to the IO's delegation contract prior to 1970. In that year, a window of opportunity opened for staff to act outside their mandate. A cholera outbreak in Guinea and the repeated refusal of the Guinean government to report led WHO bureaucrats-Director-General Marcolino Candau, the WHO Committee on Communicable Diseases, and the EB-to exceed their delegated authority. The Guinean government never notified the WHO, but Candau went ahead and reported the outbreak using information from a variety of sources. In response, Guinean officials threatened to quit the WHO and called the IO's reports 'malevolent and illegal' (New York Times 1970). Candau recognised that his actions were outside the IHR, but he argued they were necessary given the WHO's responsibility under Article 2 of its constitution (Fidler 2004: 64).

The WHO bureaucrats' actions in the cholera case were tempered by their concern for their organisation's security. WHO staff acted on their preferences in 1970, but they had not done so under similar pressures on numerous occasions. The El Tor cholera pandemic originated in Indonesia in 1961, and subsequent outbreaks occurred throughout Asia, the Soviet Union, and Western Europe (New York Times 
1970; WHO 'Global Epidemics'). Despite the fact that other countries failed to report these outbreaks to the WHO, as was required under the ISR, it was only when the disease reached Africa in 1970, that the WHO acted. The same IO bureaucrats had made no attempt to challenge more strategically important countries. ${ }^{17}$

Another window of opportunity opened in the 1990s, leading WHO staff to attempt to change the IHR themselves. By this time, the WHO was under attack for its inability to deal with international health issues, particularly HIV/AIDS (e.g. Godlee 1994a, 1994b). The staff grew increasingly frustrated by the IHR's ineffectiveness, states' repeated failures to notify the WHO of cases of even the three diseases they were required to report, and the IHR's apparent irrelevance to the growing HIV/AIDS pandemic (Fidler 2004: 35-41).

At about the same time, improvements in information technology created an opportunity for the WHO staff to act. In 1994 an NGO launched the Program for Monitoring Emerging Diseases (ProMED), a subscriber-based reporting system. In 1997 the WHO began working with Health Canada on the Global Public Health Intelligence Network (GPHIN), an internet-based system for monitoring news sources for evidence of disease outbreaks. The staff also began informally operating its own Global Outbreak Alert and Response Network (GOARN) (Fidler 2004: 63-67, 2005: 347). ${ }^{18}$ In sum, the WHO's perceived inaction on HIV/AIDS undermined its legitimacy, while the opportunities posed by the advent of the internet created new ways for the WHO's public health and medical staff to advance their preferences.

In response to these pressures and opportunities, WHO bureaucrats sought to expand the IO's authority. In 1995 Director-General Hiroshi Nakajima presented a draft resolution for the upcoming WHA meeting, recommending the WHO coordinate efforts to improve national and international capacities for infectious disease surveillance. In response, member states authorised the director-general to begin updating the IHR and developing improved strategies for combatting emerging infectious disease threats. By 1998 the director-general produced a Provisional IHR Draft that incorporated WHO authority to use non-state sources of epidemiological information and to report clinical symptoms, rather than specific diseases (Fidler 2005). ${ }^{19}$ Efforts to change the IHR required member state approval, however, and the revision process stalled. The WHO Secretariat issued a new report in 2001 again recommending that the IHR allow reporting of public health risks, rather than specific diseases, and that reporting occur by both countries and the WHO's GOARN (WHO 2001: 4). The Secretariat set a May 2004 deadline for completing revisions and issued a discussion paper on proposed changes (Davies et al. 2015: 2-3; also see Fidler 2005: 354). Despite staff efforts, however, the existing delegation contract prevented them from advancing IHR reform on their own.

\footnotetext{
17 We thank an anonymous reviewer for their comments on this point.

18 GOARN was formally established in 2000.

19 The Provisional Draft was never submitted to the EB because of problems in pilot studies on syndromic notification (Fidler 2005: 350).
} 
The situation changed in 2003, when the highly contagious SARS virus created a new threat to the WHO's legitimacy and opened another window of opportunity. In light of previous criticisms of the WHO for its lackluster response to HIV/AIDS, staff felt they could not afford to be passive, and new technologies offered an opportunity to act. In February the WHO Secretariat acted autonomously when it relied on a GPHIN alert, an NGO source, to request additional information from the Chinese government on a disease outbreak not subject to the existing regulations. Based on this information, which suggested not only that the epidemic might have begun in Guangdong and was continuing to spread, but also that the Chinese were not cooperating, WHO officials 'went on the offensive against China' (Fidler 2004: 96), repeatedly accusing its government of denying WHO staff access to the province. In April Director-General Gro Harlem Brundtland publicly criticised China: 'It would have been definitely helpful if the international expertise and WHO had been able to help at an earlier stage. When I say that it would have been better, it means that I'm saying as the director general of the World Health Organisation: next time something strange and new comes anywhere in the world let us come in as quickly as possible' (China Under Fire 2003).

In response to SARS, the WHO issued a series of unprecedented emergency alerts. To curb the spread of the disease, it warned travellers to stay away from Hong Kong, Toronto, Taiwan, and parts of China and imposed conditions for ending the travel advisories. The WHO acted despite protests from Canada and China, which argued that the measures adversely impacted tourism and trade. The IO's actions in the SARS case, while consistent with its overall mission, were beyond the discretion specifically granted to the staff in the area of disease surveillance and response. Indeed, the WHO acted 'well beyond [even] the authority it was proposing to write into the revised IHR [...]. [T] he most radical of all the WHO recommendations - the geographically-specific travel advisories-were directed at travellers not WHO member states' (Fidler 2004: 139-40). Although WHO staff exceeded their mandate, the travel advisories singled out only a few states, so the consensus (or super-majority) decision rule made it unlikely the WHA would rein in the errant bureaucrats.

Director-General Brundtland provided leadership in responding to the SARS outbreak, but numerous WHO officials participated in 'the offensive against China' (Fidler 2004: 96). David Heymann (2013), WHO executive director of communicable diseases during the SARS outbreak, describes Brundtland's decisions as 'bold because they were made purely on the basis of rapidly accumulating scientific evidence, because they put concerns for public health first and foremost, and because they were made despite concerns about potential political pressures'. At the same time, the WHO's Western Pacific Regional Office and the WHO representative in China, in particular, played significant roles in criticising China's failure to report and advising national governments, the medical community, and the media about SARS (Davies et al. 2015: Ch. 2).

In the wake of the SARS epidemic the WHA unanimously called for completion of the IHR revision. The WHA requested that in the future the director-general 'take into account reports from sources other than official notifications [... and] alert, when necessary and after informing the government concerned, the international 
community to the presence of a public health threat that may constitute a serious threat to neighbouring countries or to international health' (WHA 2003). Member states, in short, soon amended the delegation contract to include the enhanced authority the WHO bureaucrats already had exercised. They also included limits on the director-general's authority to issue recommendations (Davies et al. 2015: 66-68), however, making future autonomy in this area less likely.

The WHO's enhanced discretion may have created both backlash to and expectations of greater action by the WHO. In the first potentially major post-SARS pandemic, the $2009 \mathrm{H} 1 \mathrm{~N} 1$ (swine flu) outbreak, "concerns were raised [from some states] over the WHO acting outside the protocols implied by delegated authority' even though the staff did not do so (McInnes 2015: 1311; also Hanrieder and Kreuder-Sonnen 2014). The 2014 Ebola crisis in West Africa led to criticism of another kind; according to McInnes (2015: 1301), the WHO came under fire largely from non-state actors 'not simply because it failed to provide sufficiently prompt warning of the developing crisis and to coordinate international response; [...] it was also implicated in the system's apparent failure to provide an adequate response'. In other words, the IO was criticised for its failure to act outside its mandate. This pattern continued when the novel coronavirus COVID-19 appeared in China late in 2019. The WHO has been widely attacked for its failure to confront a powerful member state on its reporting obligations and for its slowness in declaring a global health emergency (Hernandez 2020). In short, while the WHO has not acted outside its mandate in the area of infectious disease surveillance since SARS, it has been criticised both for exceeding its mandate in the H1N1 case and for not going far enough-moving beyond surveillance and technical advice into operational capacity, an area outside its mandate-in the Ebola and COVID-19 cases.

The conditions we identify as enabling IOs to act outside their delegation contracts were present when the WHO exercised autonomy in response to cholera and SARS: agents were selected on the basis of their expertise, a window of opportunity created external pressures on the WHO, delegation was discretion-based, and voting rules were dispersed. In addition, the director-general had the authority to speak for the organisation on disease surveillance and response. Although she did not act alone, Director-General Brundtland exhibited exceptional leadership in the SARS crisis. Her actions in defense of global health during the SARS crisis were clearly outside the WHO's mandate and consistent with our argument about when IO bureaucrats engage in autonomous behaviour.

\section{The World Trade Organization}

The WTO took effect in January 1995 following the completion of the nearly eightyear Uruguay Round of multilateral trade negotiations. Its 164 member states retain considerable control over the organisation's two main bodies. The Secretariat, overseen by a director-general appointed by member states, advises and assists members in fulfilling the WTO's mandate. The Secretariat has been delegated little discretion and member state representatives at the WTO's headquarters in Geneva play an 'active role [...] in the WTO's day-to-day activities' (Blackhurst 1998: 36). The 
Appellate Body ( $\mathrm{AB})$, a standing judicial entity comprising seven individuals who serve on the basis of their expertise for four-year terms that are renewable only once, is the final arbiter of disputes between states regarding the compatibility of their policies with the WTO agreements. It acts independently of the Secretariat, has its own small secretariat, and reviews only those legal questions brought to it by a member state appealing a lower panel's decision. The AB cannot 'remand a dispute to a panel for further consideration', cannot 'decline to hear an appeal', or 'refrain from addressing a legal issue properly raised in an appeal' (Bacchus 2002: 1028). In this regard, 'the negotiating history strongly indicates that [the $\mathrm{AB}$ ] was intended not as an international court, but as a check on occasional egregious mistakes by panels. [...] [I]t was to make recommendations so as to assist [member states] to resolve disputes' (Graham 2020: 10).

Article 17.3 of the Dispute Settlement Understanding (DSU) (WTO 'Understanding on Rules') notes that $\mathrm{AB}$ members are expected to be 'persons of recognised authority, with demonstrated expertise in law, international trade and the subject matter of the covered agreements generally'. AB members are appointed by consensus of the member states. 'Each appeal is heard by a division of three [AB] members' who are assigned randomly; thus, it is possible for one to be a citizen of a disputant (Picciotto 2005: 489). 'The Working Procedures require that all seven members [discuss each] appeal to encourage consistency and coherence of decisions' (Steger 2017: 11); and the AB members themselves decided 'there would be no dissents' (Steger 2017: 12).

Within its purview, the $\mathrm{AB}$ enjoys considerable discretion. First, the $\mathrm{AB}$ establishes its own procedures for handling disputes. Second, the treaty establishing the WTO often does not precisely specify member state obligations. Therefore, 'the delegation of power to adjudicate disputes about the meaning of the WTO agreements inevitably also entails a delegation of authority to interpret them, to the extent that the texts are indeterminate' (Picciotto 2005: 490-91).

The voting rules that coordinate states' oversight of the IO make it difficult for the states to limit the AB's use of its discretion. In particular, member states, acting as the Dispute Settlement Body, can reject the AB's recommendations only if all member states agree not to accept them (WTO 'Understanding on Rules': Article 17.14). A similar consensus voting rule also applies to changes in the delegation contract. ${ }^{20}$ Therefore, several of the conditions that make IO autonomy possible characterise the WTO's structure: the AB's members are selected on the basis of their expertise, it enjoys discretionary-based delegation, and decision-making authority among states is dispersed.

When the AB was first staffed in 1995, according to Elsig and Pollack (2014: 404), states undertook 'little screening of members with respect to their views on specific issues'. They instead emphasised 'the eminence and expertise of the candidates' as well as 'concerns about national representation and geographic

\footnotetext{
${ }^{20}$ The WTO agreement permits some decisions outside the Dispute Settlement Understanding to be made if a majority or a three-fourths majority votes in favour. To date, member states have not taken a vote, preferring to abide by the practice of reaching decisions by consensus.
} 
diversity' (ibid.). As experts charged with a specific mandate, the original AB members developed independent preferences. Given the newness of the organisation, they were concerned with enhancing their institution's legitimacy, independence, reputation, and the rule of law more generally. For example, Claus-Dieter Ehlermann, an AB member from 1995 to 2001, explains (2003: 695-96) that he and his colleagues wanted 'to contribute to the strength and authority of the' $\mathrm{AB}$ and 'contribute to the building of a new independent institution'. James Bacchus, the chair of the original group of seven AB members, notes that the AB's 'goal from the very start was the establishment of an independent, quasi-judicial institution that would serve all the Members of the WTO equally and effectively' (Bacchus 2003: 7). As a consequence, the AB developed an identity that contrasted with member states' original vision for the unit.

For the most part the $\mathrm{AB}$ has acted in accordance with the discretion it has been delegated to resolve trade disputes between states. Sometimes it has been asked to resolve procedural disagreements. In 1997, for example, the AB reversed a panel's decision to disallow Saint Lucia's use of private counsels during the dispute hearings. Even though such a practice had not occurred in the history of the WTO or its predecessor, the General Agreement on Tariffs and Trade (GATT), the $\mathrm{AB}$ identified nothing in the treaty to prohibit a member state from determining the composition of its own delegation (Smith 2004: 566). In addition, the $\mathrm{AB}$ saw the use of private counsel as improving the quality of dispute settlement proceedings and member states' participation in them (ibid.). Similarly, in 2008 the AB endorsed the two disputants' agreement to open the panel hearing to the public. In agreeing that appellate hearings could also be open, 'the AB gave a flexible interpretation to the confidentiality requirement in Article 17.10 of the DSU, by rejecting that this requirement means the same in all relations, is absolute and incapable of derogation [...]. The $\mathrm{AB}$ also stated that a request for an open hearing satisfies the requirements of fairness and integrity that are the essential attributes of the appellate process' (Ehring 2008: 1029). In both cases, the $\mathrm{AB}$ acted on its discretion in the manner states intended; it used its expertise to render an impartial ruling on legal issues raised by the actions of the member states involved in the dispute.

During this period, the $\mathrm{AB}$ on one occasion exercised its discretion in a way member states did not intend by granting standing to NGOs. Its 1998 decision to permit amicus curiae (friend-of-the-court) briefs from non-state actors, emerged in the background of a crisis situation affecting the WTO and international economic organisations more generally. The organisation at the time was under fire from NGOs for a lack of transparency, a democratic deficit, and a lack of concern for anything but free trade. Similar legitimacy concerns were raised about the International Monetary Fund and World Bank, and NGOs had assumed a high profile role in the recent failure of the Multilateral Agreement on Investment (see de Jonquieres 1998). With some WTO members, including the United States, calling for the WTO to find ways to become more accountable and open to interest groups, several environmental NGOs took the unprecedented step of filing amicus briefs with the panel involved in the Shrimp-Turtle case in 1997. For the AB, whose members were focused on developing the dispute settlement system's legitimacy, these pressures challenged 
the organisation's security and opened a window of opportunity to consolidate public support for the dispute settlement system.

Amicus briefs and the role of NGOs were discussed during the Uruguay Round negotiations, but member states opted against developing procedures for incorporating either. That decision continued the GATT panel process' longstanding practice of not accepting amicus briefs from non-members in trade disputes. Thus, the NGOs' actions in this case fell outside the rules members had devised for the dispute process, and the states involved protested. The AB (WTO 1998b) nevertheless ruled that nothing in the DSU prohibits amicus briefs from private individuals or groups; moreover, DSU Article 13 grants panels broad discretion to seek any information they deem necessary to assess the facts of the case. This ruling led to criticism from the majority of member states who saw the $A B$ as altering the Uruguay Round agreements to create new obligations (see WTO 1998a). Since some states supported the ruling, however, the consensus voting rule worked against a change in the delegation contract.

A similar result occurred in 2000 when the admissibility of amicus briefs was contested at appellate review (see WTO 2000). The AB permitted them and established a process for their submission in that appeal, noting that it had the authority to develop procedural rules when they were absent from the treaty. ${ }^{21}$ Bacchus (2004: 4) explained this decision in the following terms: 'The opportunity to submit amicus briefs can give those from the wider world the chance to have their say-without in any way undermining the essential intergovernmental nature of such proceedings. Amicus briefs can provide an additional and valuable point of view-as they do for judiciaries throughout the world'. Moreover, use of amicus briefs aligned with the $\mathrm{AB}$ members' belief that their " "range of duty" is to the entire population of all of the 146 members of the WTO' (Bacchus 2003: 7). Yet, as Steinberg (2004: 251) writes, 'the Appellate Body's interpretation of Article 13 was made in the context of several years of North-South deadlock over whether to permit amicus briefs. Few developing countries would have consented to an agreement with that outcome, yet the Appellate Body interpreted the DSU as supporting it'. Given the consensus voting rule, however, those countries opposed to the AB's action could not overturn it in the face of other states' support.

The $\mathrm{AB}$ continued to accept amicus submissions from non-state actors in subsequent cases (Steger 2017: 15), institutionalising this new right for non-members. Nonetheless, the AB has not exercised autonomy again when adjudicating disputes even though there have been no changes to the delegation contract or voting rules. The AB's restraint emerges from member states' reactions to the amicus decision which had a 'chilling effect on the AB' (ibid.). Over the next twenty years, moreover, member states instituted a series of strategies to reduce the AB's capacity to carry out its discretion. In 2002 states proposed reforms to the DSU that would impact

\footnotetext{
${ }^{21}$ See Howse (2003) for a detailed analysis of both decisions. The AB's decision allowed unsolicited amicus briefs; the states involved in the case did not solicit them in support of their positions. As Howse (2003: 508) points out, the authority to accept amicus briefs also comprises the authority to consider them when making rulings.
} 
the $A B$ 's discretion, ${ }^{22}$ thereby affecting the AB's sense of organisational security. ${ }^{23}$ Although the consensus voting rule made agreement elusive on a new delegation contract, some member states redoubled their use of existing ex ante and ex post oversight mechanisms of AB members (Elsig and Pollack 2014: 406-409). This attention materialised in a 'trend' towards 'the appointment of ex-ambassadors (i.e. politically experienced individuals) as opposed to individuals with more legal experience' (Appleton 2016: 27). Recruitment processes shifted, leading to the appointment of $\mathrm{AB}$ members with different training and backgrounds to reduce the potential for independence. ${ }^{24}$ Starting in 2016 and reflecting longstanding concerns about the AB's procedures and interpretations, ${ }^{25}$ as well as frustration with other WTO members (Hillman n.d.: 4-5; Graham 2020: 2), the United States first blocked reappointments and then new appointments to the AB. Beginning in September 2018, this strategy reduced the body to only three members, the minimum quorum required. With two members' terms set to expire in 2019 and continued disagreements among member states about the needed reforms, the AB's future was in doubt. It ceased operations in March 2020 when the states cut most of its funding and it now exists only 'on paper' (Graham 2020: 6).

The conditions we identify as enabling IOs to act outside their delegation contract were present when the $\mathrm{AB}$ granted standing to NGOs: members of the $\mathrm{AB}$ were selected on the basis of their expertise; an external pressure opened a window of opportunity for them to advance their preferences; delegation was discretion-based; voting rules were dispersed; and the $\mathrm{AB}$ enjoyed the capacity to act independently of other elements of the WTO's bureaucracy. The AB has not acted autonomously again, however, as many member states viewed its unintended action as undesired and took steps to limit its reappearance.

\section{Conclusion}

This article contributes to an understanding of IO autonomy in two ways. First, we underscore the need to conceptualise autonomy to include only IO behaviour that is unintended by member states, and we use the IO's delegation contract to distinguish between IO bureaucrats' intended and unintended actions. Having a clear baseline by which to measure autonomy is essential if we are to compare systematically the role IO bureaucrats can and do play in world politics. Second, we draw on insights developed in work on exogenous pressures for change to add a missing step to constructivist and P-A approaches' understanding of IO

\footnotetext{
22 Over time, the desire for DSU reform went beyond the AB's decision on amicus briefs and included states, such as the United States, that were unhappy with rulings on their trade policies.

23 One indication is that the $\mathrm{AB}$ never again implemented procedures for the submission of amicus briefs.

24 More vigorous screening processes did not lead member states to become more satisfied with their candidates. The United States, for example, did not seek a second term for two AB members who previously worked at the Office of the United States Trade Representative.

25 For an overview of some of these interpretations, see Steinberg (2004).
} 
autonomy: when and why international bureaucrats advance their preferences and act outside the delegation contract. Autonomous behaviour is most likely when: IO staff are selected on the basis of their specialised knowledge; an external pressure influences the IO's ability to fulfill its mandate; the delegation contract grants discretion to IO bureaucrats; voting rules require coordination among multiple member states to restrain IO bureaucrats; and the structure of decision-making within the IO's bureaucratic apparatus limits the number of units involved in the policy area.

A central element of our approach is that autonomy emerges not just from the delegation and pooling of authority but also from IO bureaucrats' interaction with their external environment. Changes in the latter can lead staff to take unintended actions in an effort to advance their organisational security. As a consequence, the factors that make IO autonomy possible are more multifaceted than constructivist and P-A approaches individually or collectively suggest. In the cases of autonomy examined here, international bureaucrats responded to external developments that had implications for their mandates, and they did so to protect their organisations' legitimacy. In doing so, the bureaucrats viewed their organisation's legitimacy through the lens of their professional training and expertise. This aspect of their identity, then, offers important insights into bureaucrats' problem definition and motivation to act in response to exogenous pressures.

The empirical analyses indicate that the nature and consequences of the delegation relationship are not fixed. In the WHO, for example, member states ultimately endorsed bureaucrats' use of new monitoring and communication methods in response to the SARS crisis and integrated them into a new delegation contract. Those actions became part of the IO's accepted procedures, providing it with new discretionary authority to respond to subsequent crises. In the WTO, most member states did not support the AB's decision to grant standing to non-members, but the procedural change was left in place due to the IO's consensus voting rule. Over time, however, other member states became frustrated with the AB's actions and found ways to curtail its capacity for independent action. The example of these two IOs indicates that bureaucrats' autonomous actions can have significant consequences not only for the IO's actions and processes but also for the principal-agent relationship itself. Therefore, the dynamics we explore also have implications for broader issues related to IO change.

Integrating core insights from constructivist and P-A approaches with a focus on exogenous pressures that impact an IO's organisational security generates a more encompassing theory of IO autonomy that explains not only why bureaucrats develop independent preferences and when they can achieve them, but also when and why agents choose to act autonomously, the missing step in the existing literature. Our three-part explanation, together with the use of a narrower understanding of the concept of autonomy, offers a framework for future studies of IO behaviour. Since we expect to see fewer examples of agent autonomy than suggested by previous literature, scholars interested in IO agency should concentrate not only on why autonomy occurs when it does but also on why other forms of IO independence happen more frequently. Doing so is likely to improve our understanding of IOs and, therefore, of global governance. 


\section{References}

Appleton, Arthur (2016) 'Judging the Judges or Judging the Members? Pathways and Pitfalls in the Appellate Body Appointment Process', in Leila Choukroune, ed., Judging the State in International Trade and Investment Law, 11-32, Singapore: Springer.

Bacchus, James (2004) 'Open Doors for Open Trade: Shining Light on WTO Dispute Settlement', Remarks to the National Foreign Trade Council, Mayflower Hotel, Washington, DC, 29 January, available at https://www.worldtradelaw.net/articles/bacchusopendoors.pdf.download (last accessed on 22 September, 2021).

Bacchus, James (2003) 'Lecky's Circle: Thoughts from the Frontier of International Law', Address to the Institute of Advanced Legal Studies, University of London, London, 10 April, available at https://www.worldtradelaw.net/articles/bacchuslecky.pdf.download (last accessed on 22 September, 2021).

Bacchus, James (2002) 'Table Talk: Around the Table of the Appellate Body of the World Trade Organization', Vanderbilt Journal of Transnational Law 35(4): 1021-39.

Barnett, Michael and Liv Coleman (2005) 'Designing Police: Interpol and the Study of Change in International Organizations', International Studies Quarterly 49(4): 593-619.

Barnett, Michael and Martha Finnemore (2004) Rules for the World: International Organizations in Global Politics, Ithaca: Cornell University Press.

Bauer, Michael W. and Jorn Ege (2016) 'Bureaucratic Autonomy of International Organizations' Secretariats', Journal of European Public Policy 23(7): 1019-37.

Biermann, Frank and Bernd Siebenhuner (2009) 'The Influence of International Bureaucrats in World Politics: Findings from the MANUS Research Program', in Frank Biermann and Bernd Siebenhuner, eds, Managers of Global Change: The Influence of International Environmental Bureaucracies, 319-49, Cambridge: MIT Press.

Biermann, Rafael and Michael Harsch (2017) 'Resource Dependence Theory', in Rafael Biermann and Joachim Koop, eds, Palgrave Handbook of Inter-Organizational Relations in World Politics, 135-55, London: Palgrave Macmillan.

Blackhurst, Richard (1998) 'The Capacity of the WTO to Fulfill its Mandate', in Anne Krueger, ed., The WTO as an International Organization, 31-58, Chicago: University of Chicago Press.

Brown, Robert L. (2010) 'Measuring Delegation', Review of International Organizations 5(2): 141-75.

Capoccia, Giovanni and R. Daniel Kelemen (2007) 'The Study of Critical Junctures: Theory, Narrative, and Counterfactuals in Historical Institutionalism', World Politics 59(3): 341-69.

'China Under Fire for Virus Spread' (2003) BBC News, 6 April, available at http://news.bbc.co.uk/2/hi/ health/2922993.stm (last accessed on 5 December, 2020).

Chorev, Nitsan (2012) The World Health Organization Between North and South, Ithaca: Cornell University Press.

Chwieroth, Jeffrey M. (2008a) 'Organizational Change "From Within": Exploring the World Bank's Early Lending Practices', Review of International Political Economy 15(4): 481-505.

Chwieroth, Jeffrey M. (2008b) 'Normative Change from Within: The International Monetary Fund's Approach to Capital Account Liberalization', International Studies Quarterly 52(1): 129-58.

Copelovitch, Mark S. (2010) 'Master or Servant? Common Agency and the Political Economy of IMF Lending', International Studies Quarterly 54(1): 49-77.

Cortell, Andrew P. and Susan Peterson (2006) 'Dutiful Agents, Rogue Actors, or Both? Staffing, Voting Rules, and Slack in the WHO and WTO', in Darren G. Hawkins, David A. Lake, Daniel L. Nielson and Michael J. Tierney, eds, Delegation and Agency in International Organizations, 255-80, Cambridge: Cambridge University Press.

Cortell, Andrew P. and Susan Peterson (1999) 'Altered States: Explaining Domestic Institutional Change', British Journal of Political Science 29(1): 177-203.

Davies, Sara E., Adam Kamradt-Scott and Simon Rushton (2015) Disease Diplomacy: International Norms and Global Health Security. Baltimore: Johns Hopkins University Press.

De Jonquieres, Guy (1998) ‘Network Guerillas’, Financial Times, 30 April: 20.

Ege, Jorn, Michael W. Bauer and Nora Wagner (2020) 'Improving Generalizability in Transnational Bureaucratic Influence Research: A (Modest) Proposal', International Studies Review 22(3): $551-75$.

Ehlermann, Claus-Dieter (2003) 'Reflections on the Appellate Body of the WTO', Journal of International Economic Law 6(3): 695-708. 
Ehring, Lothar (2008) 'Public Access to Dispute Settlement Hearings in the World Trade Organization', Journal of International Economic Law 11(4): 1021-34.

Elsig, Manfred and Mark Pollack (2014) 'Agents, Trustees, and International Courts: The Politics of Judicial Appointment at the World Trade Organization', European Journal of International Relations 20(2): 391-415.

Fidler, David P. (2005) 'From International Sanitary Conventions to Global Health Security: The New International Health Regulations', Chinese Journal of International Law 4(2): 325-92.

Fidler, David P. (2004) SARS, Governance, and the Globalization of Disaster, New York: Palgrave Macmillan.

Godlee, F. (1994a) 'WHO in Crisis', British Medical Journal 309: 1424-28.

Godlee, F. (1994b) 'WHO in Retreat: Is It Losing Its Influence', British Medical Journal 309: 1491-95.

Gould, Erica R. (2006) 'Delegating IMF Conditionality: Understanding Variations in Control and Conformity', in Darren G. Hawkins, David A. Lake, Daniel L. Nielson and Michael J. Tierney, eds, Delegation and Agency in International Organizations, 281-311, Cambridge: Cambridge University Press.

Graham, Erin R. (2014) 'International Organizations as Collective Agents: Fragmentation and the Limits of Principal Control at the World Health Organization', European Journal of International Relations 20(2): 366-90.

Graham, Thomas R. (2020) 'The Rise (and Demise?) of the WTO Appellate Body', John D. Greenwald Memorial Lecture, Georgetown Law International Trade Update, available at https:/www.wto.org/ english/tratop_e/dispu_e/farwellspeechtgaham_e.htm (last accessed on 17 April, 2021).

Haftel, Yoram and Alexander Thompson (2006) 'The Independence of International Organizations: Concept and Applications', Journal of Conflict Resolution 50(2): 253-75.

Hall, Nina and Ngaire Woods (2018) 'Theorizing the Role of Executive Heads in International Organizations', European Journal of International Relations 24(4): 865-86.

Hanrieder, Tine and Christian Kreuder-Sonner (2014) 'Who Decides on the Exception? Securitization and Emergency Governance in Global Health', Security Dialogue 45(4): 331-48.

Hawkins, Darren and Wade Jacoby (2008) 'Agent Permeability, Principal Delegation, and the European Court of Human Rights', Review of International Organizations 3(1): 1-28.

Hawkins, Darren G., David A. Lake, Daniel L. Nielson and Michael J. Tierney, eds (2006a) Delegation and Agency in International Organizations, Cambridge: Cambridge University Press.

Hawkins, Darren G., David A. Lake, Daniel L. Nielson and Michael J. Tierney (2006b) 'Delegation under Anarchy: States, International Organizations, and Principal-Agent Theory', in Darren G. Hawkins, David A. Lake, Daniel L. Nielson and Michael J. Tierney, eds, Delegation and Agency in International Organizations, 3-38, Cambridge: Cambridge University Press.

Hernandez, Javier C. (2020) 'Trump Slammed the W.H.O. Over the Coronavirus: He's Not Alone', New York Times, 29 May, available at https:/www.nytimes.com/2020/04/08/world/asia/trump-who-coron avirus-china.html (last accessed on 5 December, 2020).

Heymann, David L. (2013) 'How SARS Was Contained', New York Times, 4 March, available at https:// www.nytimes.com/2013/03/15/opinion/global/how-sars-was-contained.html (last accessed on 5 December, 2020).

Hillman, Jennifer (n.d.) 'Three Approaches to Fixing the World Trade Organization's Appellate Body: The Good, the Bad and the Ugly?', Institute of International Economic Law Issue Brief, Georgetown University Law Center, available at https://georgetown.app.box.com/s/966hfv0smran4m31bibl gfszj42za40b (last accessed on 17 April, 2021).

Hooghe, Liesbet and Gary Marks (2015) 'Delegation and Pooling in International Organizations', Review of International Organizations 10(3): 305-28.

Hooghe, Liesbet, Gary Marks, Tobias Lenz, Jeanine Bezuijen, Besir Ceka and Svet Derderyan (2017) Measuring International Authority: A Postfunctionalist Theory of Governance, Volume III, Oxford: Oxford University Press.

Howse, Robert (2003) 'Membership and its Privileges: The WTO, Civil Society, and the Amicus Brief Controversy', European Law Journal 9(4): 496-510.

Ikenberry, G. John, David Lake and Michael Mastanduno, eds (1988) The State and American Foreign Economic Policy, Ithaca: Cornell University Press.

Jacobson, Harold K. (1973) 'WHO: Medicine, Regionalism, and Managed Politics', in Robert Cox and Harold Jacobson, eds, The Anatomy of Influence: Decision Making in International Organization, 194-205, New Haven: Yale University Press. 
Johnson, Tana (2014) Organizational Progeny: Why Governments are Losing Control over the Proliferating Structures of Global Governance, Oxford: Oxford University Press.

Johnson, Tana and Johannes Urpelainen (2014) 'International Bureaucrats and the Formation of Intergovernmental Organizations: Institutional Design Discretion Sweetens the Pot', International Organization 68(1): 177-209.

Keeler, John T.S. (1993) 'Opening the Window for Reform: Mandates, Crises, and Extraordinary Policymaking', Comparative Political Studies 25(4): 433-86.

Kingdon, John (1984) Agendas, Alternatives, and Public Policies, New York: Harper Collins.

Knill, Christoph, Louisa Bayerlein, Jan Enkler and Stephan Grohs (2019) 'Bureaucratic Influence and Administrative Styles in International Organizations', Review of International Organizations 14(1): 83-106.

Legro, Jeffrey W. (2000) 'Whence American Internationalism', International Organization 54(2): 253-89.

McInnes, Colin (2015) 'Who's Next? Changing Authority in Global Health Governance After Ebola', International Affairs 91(6): 1299-316.

Natorski, Michal (2016) 'Epistemic (Un)certainty in Times of Crisis: The Role of Coherence as a Social Convention in the European Neighborhood Policy after the Arab Spring', European Journal of International Relations 22(3): 646-70.

New York Times (1970) '60 Reported Dead in Guinea of Cholera', New York Times, 2 September: 1.

Nielson, Daniel L. and Michael J. Tierney (2003) 'Delegation to International Organizations: Agency Theory and World Bank Environmental Reform', International Organization 57(2): 241-76.

Nielson, Daniel L., Michael J. Tierney and Catherine E. Weaver (2006) 'Bridging the Rationalist-Constructivist Divide: Re-Engineering the Culture of the World Bank', Journal of International Relations and Development 9(2): 107-139.

Picciotto, Sol (2005) 'The WTO's Appellate Body: Legal Formalism as a Legitimation of Global Governance', Governance 18(3): 477-503.

Smith, James (2004) 'Inequality in International Trade? Developing Countries and Institutional Change in WTO Dispute Settlement', Review of International Political Economy 11(3): 542-73.

Steger, Debra P. (2017) 'The Founding of the Appellate Body', Working Paper Series 2017-33, University of Ottawa, Faculty of Law, available at https://ssrn.com/abstract=3010311 (last accessed on 22 September, 2021).

Steinberg, Richard (2004) 'Judicial Lawmaking at the WTO: Discursive, Constitutional and Political Constraints', American Journal of International Law 98(2): 247-75.

Williams, Douglas (1987) The Specialized Agencies and the United Nations, New York: St. Martin's.

World Health Assembly [WHA] (2003) Revision of the International Health Regulations WHA 56.28, 28 May, available at https://apps.who.int/gb/archive/pdf_files/WHA56/ea56r28.pdf (last accessed on 5 December, 2020).

World Health Organization (n.d.) 'Global Epidemics and Impact of Cholera', available at https://www. who.int/topics/cholera/impact/en (last accessed on 5 December, 2020).

World Health Organization (n.d.) 'How WHO is Funded', available at https://www.who.int/about/funding (last accessed on 5 December, 2020).

World Health Organization (2008) '61 ${ }^{\text {st }}$ World Health Assembly: Daily Notes on Proceedings', available at https://www.who.int/mediacentre/events/2008/wha61/journal/en/ (last accessed on 5 December, 2020).

World Health Organization (2001) 'Global Health Security-Epidemic Alert and Response', Report by the Secretariat, A54/9, 2 April, available at https://apps.who.int/iris/handle/10665/78718 (last accessed on 20 May, 2021).

World Health Organization (1983) International Health Regulations $1969,3^{\text {rd }}$ annotated edition, available at https://apps.who.int/iris/handle/10665/96616 (last accessed on 20 May, 2021).

World Health Organization (1948) Constitution of the World Health Organization, available at https:// www.who.int/about/who-we-are/constitution (last accessed on 10 April, 2021).

World Trade Organization (n.d.) 'Understanding on Rules and Procedures Governing the Settlement of Disputes', available at https://www.wto.org/english/tratop_e/dispu_e/dsu_e.htm\#17 (last accessed on 16 April, 2021).

World Trade Organization (2000) 'Minutes of Meeting', General Council, WT/GC/M/60, 22 November, available at https://docs.wto.org/dol2fe/Pages/SS/directdoc.aspx?filename=Q:/WT/GC/M60.pdf\& Open=True (last accessed on 16 April, 2021). 
World Trade Organization (1998a) 'Minutes of Meeting', Dispute Settlement Body, WT/DSB/M/50, 6 November, available at https://docs.wto.org/dol2fe/Pages/SS/directdoc.aspx?filename=Q:/WT/ $\mathrm{DSB} / \mathrm{m} 50$. pdf\&Open=True (last accessed on 16 April, 2021).

World Trade Organization (1998b) 'United States - Import Prohibition of Certain Shrimp and Shrimp Products: Report of the Appellate Body', WT/DS58/AB/R, 12 October, available at https://docs. wto.org/dol2fe/Pages/SS/directdoc.aspx?filename=Q:/WT/DS/58ABR.pdf\&Open=True (last accessed on 16 April, 2021).

Publisher's Note Springer Nature remains neutral with regard to jurisdictional claims in published maps and institutional affiliations.

Andrew P. Cortell is Professor of Political Science and Chair of the Department of Political Science and Public Administration at Auburn University at Montgomery. His current research focuses on the sources and consequences of delegation of authority to international organisations.

Susan Peterson is the Wendy and Emery Reves Professor of Government and International Relations and Chair of the Government Department at William \& Mary. Her research focuses on the domestic politics of international conflict, the politics of global health, and the relationship between the theory and practice of international relations. 